\author{
Бошко СУВАЈџИһ \\ Универзитет у Београду \\ Филолошки факултет
}

\title{
КОСОВСКА ЛЕГЕНДА
}

\begin{abstract}
Косовска легенда је место сусретања различитих слојева традиције: локалног предања, забележеног на Косову; светитељског култа кнеза Лазара, који је негован у Српској деспотовини старањем Лазаревих наследника, и витешке приче о Милошу Обилићу, посебно развијене у западним, приморским крајевима. Сам историјски догађај се у свести савременика урезао као пресудна борба, као сукоб две цивилизације, две вере и два принципа до те мере, да су га наредна покољења обликовала са једнаком свешћу о његовом преломном и усудном значају, и са једнаком, ако не и већом преданошћу.
\end{abstract}

У предговору првој књизи српских народних песама лајпцишког издања (1824) Вук Караџић је истакао да ,јуначких пјесама мало имамо старији од Косова, а од Немањића нема старије ниједне”, да би, даље, наставио сада већ чувеном реченицом: „Ја мислим, да су Србљи и прије Косова имали и јуначких пјесама од старине, но будући да је она премјена тако силно ударила у народ, да су готово све заборавили, што је било донде, па само оданде почели наново приповиједати и пјевати." Косовски бој се тако с правом вековима намеће као коренита „премјена”, међаш српске историје и народног памћења.

Да Косово у српској колективној свести постане „тип” бојног поља, „разбојишта”, али и „саборишта” хришћанске господе која се ту окупља да размотри сва важна питања српске усмене духовности, да стави на кантар заслуге светородних предака („куд се ђеде цар-Немање благо”), али и одреди моралне принципе по којима се човеку ваља владати на овоме пропадљивом свету (,Урош и Мрњавчевићи”), највише су допринела два боја која су се одиграла у XIV и XV веку: онај чувени, први, који је трајао само један дан или, можда, само једно преподне, 28. јуна (15. јуна по старом календару) 1389. године, између султана Мурата I и кнеза Лазара; и 
други, који је трајао три дана, од 17. до 19. октобра 1448. године, између султана Мурата II и намесника Угарске, Хуњади Јанка (Сибињанин Јанко наше усмене епске традиције).

Косовска легенда је место сусретања различитих слојева традиције: локалног предања, забележеног на Косову; светитељског култа кнеза Лазара, који је негован у Српској деспотовини старањем Лазаревих наследника, и витешке приче о Милошу Обилићу, посебно развијене у западним, приморским крајевима. Сам историјски догађај се у свести савременика урезао као пресудна борба, као сукоб две цивилизације, две вере и два принципа до те мере, да су га наредна покољења обликовала са једнаком свешћу о његовом преломном и усудном значају, и са једнаком, ако не и већом преданошћу.

Косовска легенда почиње да се ствара одмах након завршеног боја. Целовит облик добија у текстовима с краја XVI и почетком XVII века. Састоји се из три слоја: 1) историјског, који чине врло магловите вести о самом догађају из 1389. године; 2) црквено-религиозног, који се обликује кроз светитељски култ кнеза Лазара; 3) епског слоја у чијој је основи витешко-феудална прича о подвигу Милоша Обилића.

\section{Косовски бој у историји}

У развоју косовске легенде историја је обликована као предање, предање као историја (М. Матицки). О самом Косовском боју данас поседујемо веома магловита сазнања будући да се историја врло рано помешала са легендом. О догађају се ништа поуздано не зна. Круже некакве гласине и сплетке које се не дају проверити. Стога сви извештаји из године боја почињу на начин усменог историјског предања: кружио је глас, приповеда се, казује се...

Обе стране су се дуго припремале за одлучујућу битку. Готово деценију пре Косовског боја летописци бележе турске упаде на територију Моравске Србије и Босне. На Косову, изузев Вука Бранковића, на чијој се територији битка и одиграла, не затичемо ни једнога од зетова и чланова „Породичног савеза” кнеза Лазара. Поред Вука Бранковића, који је успешно предводио десно крило у боју, недвосмислено је још потврђено једино учешће једног одреда „краља Срба и Босне” Твртка I Котроманића, на челу са прослављеним војсковођом Влатком Вуковићем. С друге стране, о значају који је султан Мурат придавао Косовском боју сведочи и то што је на Косово кренуо лично, са оба своја сина, најзнаменитијим војсковођама, и војском увећаном помоћним одредима из Мале Азије и са Балкана (Михаљчић 1989: 115).

Што се тиче броја српске и турске војске, о томе не можемо имати никакве прецизније податке. По Слову о кнезу Лазару Раваничанина III 
(између 1392. и 1398. године) Турака је било триста хиљада, Срба три пута мање. Турски извори, с друге стране, теже да преувеличају број непријатељске војске, како би што значајнијом представили своју победу, онако како је они, касније, виде. Турски историчар Мула Мехмед Нешри, тако, тврди да је српска војска бројала невероватних пола милиона војника, од чега триста хиљада оклопника, док је Турака било мање од сто педесет хиљада. Ни много примереније бројке које помиње у Паризу савременик битке Филип Мезијер, а по коме су обе стране располагале са по двадесет хиљада војника, не могу нам бити од велике помоћи у расветљавању догађаја. Оно што се може претпоставити, с обзиром на величину и снагу државе кнеза Лазара, и моћ Турског царства, које је већ од Маричког боја представљало, поред азијске, и европску силу, говори нам посредно да су Турци морали бити знатно бројнији.

Зна се поуздано да су у Косовском боју погинула оба владара, као и султанов син Јакуб. То је и најважнији разлог зашто је у савременим историјским изворима Косовски бој схваћен као изузетан догађај. Извесно је да је бој преживео кнежев зет, Вук Бранковић. У Босну се, са својим одредом, по краљу Твртку, готово без губитака и победоносно, вратио војвода Влатко Вуковић. С друге стране, турска војска се журно повукла са Косова у Једрене, тадашњу турску престоницу, јер се други султанов син, Бајазит, уплашио немира који су завладали у Турском царству. На попришту сукоба остао је велики број и турске и хришћанске војске. Према најранијим изворима, Косовски бој је, у војничком смислу, представљао српску победу. ${ }^{1}$

Чини се да је управо због султанове погибије и вести о српској победи, сам догађај тако снажно одјекнуо у Европи. Из године Боја, међутим, сачуван је тек невелик број оскудних извора. Најпре, неколико успутних летописних записа приликом писања (преписивања) средњовековних рукописа из 1389. године. Запис Божидара преписивача („Писа Божидар сију књигу в дан благочастиваго кнеза Лазара кадно дође цар Јамурат на Ситницу и бише бој месеца јуна 15 дан на Косову.”), Пахомијев запис („Писа се ова света књига Отачник, која се зове Лапсаитик, у дане благоверног Вука Стефана. Те године када Турци убише кнеза Лазара, а цара Амурата Србљи. Хвала Богу за све.”), запис Михаила Псела, који сведочи „колика туга беше (те године) по земљи када погибе кнез (Лазар и Мурат) велики цар турски.” У старом српском језику реч „туга” је означавала и стања узнемирености, неспокојства или стрепње (Ивић 1993: 86-90). И заиста: немир, неспокојство и стрепња представљају преовлађујуће стање

\footnotetext{
${ }^{1}$ „Сви до сада познати извори из саме године боја на Косову, изазвани самим догађајем, или сасвим отворено славе хришћански тријумф, или су прилично неодређени: о турској победи не говори ни један” (Динић 1930: 138).
} 
духа после Косовског боја. О томе сведочи и грозничави запис руског путописца ђакона Игњатија, пратиоца московског митрополита Пимина на његовом путу за Цариград, забележен дванаест дана после Косовског боја, на турској територији: „Мурат је био отишао у рат против Лазара, српског витеза; а кружио је глас да су обојица, Мурат и Лазар, били убијени у једној бици. Застрашен овим немирима, пошто смо се налазили у држави турској, митрополит отпусти монаха Михаила; епископ Михаил отпусти мене, Игњатија и Сергија Азакова, свога монаха" (Радојичић 1937: 52).

О општој атмосфери узнемирености и метежа након Косовског боја сведочи и упутство које млетачко веће крајем јула даје посланику отправљеном на двор у Једрене новом султану (посланик је добио два писма са истоветном садржином - једно за Бајазита, друго за Јакуба), „којему ће казати да смо прије одласка ових галија из Млетака дочули, али не јасно, о рату, који је био између велеможнога господина Мурада, оца његова, и кнеза Лазара, о ком су се разне ствари говориле, којима се ипак вјеровати не може; али смо ипак дочули за смрт реченога господина Мурада ради које веома жалимо" (Рачки 1992: 395). Млечани, дакле, још увек не знају ко је султана наследио на престолу, а опрезна формулација о вестима „којима се ипак вјеровати не може” посредно говори колико су те вести морале бити неповољне по турску страну.

Најзанимљивије, и најмање очекиване, јесу вести које дознајемо из писма краља Твртка I Котроманића Трогиранима од 1. августа 1389. године, у коме их „краљ Срба и Босне” обавештава да је султана „послао с овог света с многим њиховим војницима", не помињући ни речју кнеза Лазара. Писмо са сличном садржином послао је краљ Твртко I и Фирентинској општини, што дознајемо из одговора Фирентинаца у писму од 20. октобра 1389. године у коме му се упућују честитке поводом победе над Турцима. Неки историчари су сматрали да не треба обраћати пажњу на ова писма, којима је краљ Твртко хтео да за себе присвоји Лазареву славу (Руварац 1887: 809), иако је у боју учествовао само један његов помоћни одред под командом Влатка Вуковића. С друге стране, разложно делују размишљања о томе како је било сасвим природно да Твртко, у складу са својим амбицијама, које су се ослањале на државно-политичку традицију Немањића - краљ Твртко I је крунисан „сугубим венцем” у Милешеви 1377. године 2

\footnotetext{
${ }^{2}$ „Везан танким родбинским нитима за Немањиће и, уједно, господар извесног дела српских земаља, увећаних поделом области жупана Николе Алтомановића, ранији босански бан - сматрао се од тог тренутка краљем Србије и Босне. Немањићку круну, којом су овенчали његову главу, наслеђивали су заједно с именом Стефан и потоњи босански краљеви. Тежина фигуративног израза 'сугуби венац' (краљевска власт над Босном и Србијом) састојала се у томе што је он био владар читаве Босне и једног дела српских земаља. Међутим, стварна политика босанског краља нашла се брзо у раскораку с круном Немањића коју је носио" (Божић 1975: 226).
} 
- разгласи својим савезницима у рату око мађарског престола вест о победи сопственог оружја будући да се сматрао савезником, али и господаром кнеза Лазара (љубинковић 1996: 29). Оно што је још важније: у Твртковом писму Трогиранима, односно у одговору Фирентинске општине, на саму вест о хришћанској победи не пада ни најмањи трачак сумње.

О хришћанском поразу не говори ни један од савремених извора, домаћих или страних. Напротив. Да је Мурат („Аморат”) потпуно побеђен у пределима Албаније, бележи у Паризу, пре октобра 1389. године, Филип Мезијер. У духу савремених извора о Косовском боју, ни солунски писац Димитрије Кидон, у писмима прогнаном византијском цару Манојлу II Палеологу, не говори о хришћанском поразу, већ славодобитно закључује: „Онај проклетник, веома осион према богу и његовој баштини а истовремено и веома дрзак према свима, сада нестаде и погибе од оних о којима је мислио да ни вест о сили, која се против њих припремаше, неће издржати, већ да ће на сам глас у океан поскакати."

Шта се доиста десило на Косову пољу тог давног 28. јуна 1389. године никада нећемо са сигурношћу знати. Писма краља Твртка, у светлу проучавања савремених извора, унела су највећу пометњу. Она, међутим, указују на дубок несклад између устаљеног схватања, изграђеног под утицајем формиране косовске легенде, о хришћанском поразу на Косову, и савремених извора из године боја који о том поразу не говоре. Сам Косовски бој, у војничком смислу, тешко да је могао представљати пораз Срба на бојном пољу. По својим далекосежним последицама, он је то, међутим, несумњиво био.

Магловит историјски костур веома рано се попуњава животворним месом легенде, и то у два своја основна приповедна тока. Један је црквено-религиозна прича о кнезу-мученику, који жртвује себе и свој народ зарад вечног и непропадљивог „царства небеског”. Други је прича о оклеветаном јунаку, који врши херојски подвиг. Као саставни део ове приче јавља се и легенда о издаји Вука Бранковића.

\section{Легенда о кнезу Лазару}

Лик кнеза Лазара припада типу владара-мученика. Као што се зна, српски кнез Лазар Хребељановић историјска је личност. Престоница му је била у Крушевцу. Подизањем задужбине, манастира Раванице, наставио је ктиторску традицију династије Немањића. Храбро се супротставио знатно надмоћнијој турској војсци на Косову 1389. године. Извео је цвет српског племства на бојно поље и у отвореној борби положио живот у одбрани отаџбине. У традицији је представљен као цар мада царску круну није носио. За њега се у косовској епици везују црквено-религиозни мотиви, као што су косовско опредељење (избор небеског царства), причешће, 
кнежева вечера, жртва, посвећење. У песмама из збирке Вука Стефановића Караџића кнез Лазар Хребељановић је представљен као „славни кнез” и „честито колено”.

У средњовековним косовским списима кнез Лазар и његови ратници представљени су са „мученичким венцем”. У Слову о кнезу Лазару патријарха Данила III (крајем 1392. или почетком 1393. године) забележен је говор српског војсковође упућен храбрим војницима пред одлучујућу битку: „Боље је нама у подвигу смрт, него ли са стидом живот. Боље је нама у боју смрт од мача примити, него ли плећа непријатељима нашим дати." Један од најлепших списа старе српске књижевности је Похвала кнезу Лазару монахиње Јефимије у којој прва српска списатељица поручује Светом кнезу Лазару: „И тако две жеље постигао си: и змаја си убио и мучења венац си примио од бога.” Деспот Стефан Лазаревић, син кнеза Лазара, у Натпису на мраморном стубу на Косову (1404) каже да је Косово поље „пуно костију” где је „негде велики самодржац, чудо земаљско, и рига српски, који се зове Лазар кнез велики", погинуо са својим војницима (в. Трифуновић 1968).

Косовска легенда је „започела да се ствара у старој књижевности, а не у народној” (Ђорђе Сп. Радојичић), вероватно већ приликом преноса посмртних остатака кнеза Лазара из Приштине у кнежеву задужбину Раваницу. У размаку од 1390. до 1420. године написано је десет средњовековних списа који прослављају живот и духовни подвиг кнеза Лазара. Тако српски владар Лазар Хребељановић постаје Свети кнез.

Сматра се да су главни разлози за стварање култа кнежева улога у измирењу Српске цркве и Цариградске патријаршије, мученичка смрт и целе мошти (Павловић 1965: 126). Вероватно је култ почео да се ствара већ приликом свечане церемоније преношења Лазаревог тела из Приштине у Раваницу. За установљење култа кнеза Лазара пресудна је била његова мученичка смрт. ${ }^{3}$

У Житију деспота Стефана Лазаревића Константина Филозофа, делу насталом између 1433. и 1439. године, налазе се у заметку сви важнији мотиви косовске епске легенде, изузев оних о завади зетова и о ухођењу турске војске. Деспотов биограф велику пажњу поклања подвигу безименог јунака на Косову, али је ипак у средишту приповедања судбина кнеза Лазара:

\footnotetext{
${ }^{3}$ „Са косовским бојем и десет списа о косовској погибији отвара се у српској књижевности нови духовни и уметнички круг у чијем средишту сада стоји подвиг смрти. (...) Као што је раније у песничком и духовном виђењу то била Света Гора Атоска, тако сада косовски бој постаје место и време највишег подвига. Отуда се, поред већ у духовном искуству постојећих и у књижевности описаних, јављају нови чиниоци подвига, који косовском страдању дају неке изразите агоналне особености” (Трифуновић 1975: 260-261).
} 
„Међу војницима који су се борили пред (војском), беше један веома благородан (Милош) ${ }^{4}$, кога оцрнише завидљивци пред господином и осумњичише као неверна. А овај да покаже верност, а уједно и храброст, нађе згодно време, устреми се ка самоме великом начелнику, као да је пребеглица, и пут му отворише. А када је био близу, изненада појури и зари мач у тога самога гордога и страшнога самодршца. Ту и сам паде од њих. У први мах одолевали су Лазареви људи и побеђивали су. Али већ не беше време за избављење. Стога и син тога цара ојача опет у тој самој бици и победи, јер је Бог тако допустио, да се и овај велики (Лазар) и они који су с њим свежу венцем мучеништва. Шта је било после тога? Постиже (Лазар) блажену смрт тако што му је глава посечена, а његови мили другови молили су усрдно да погину пре њега, да не виде његову смрт" (Константин Филозоф 1989: 84-85).

Већ самом природом списа, лик кнеза Лазара потискује значај Милошева подвига у други план. Истина, најважнији елементи приче о Милошу Обилићу већ су ту: облагивање ,завидљиваца”, извршење подвига оклеветаног витеза као једини начин доказивања верности господару, лична мотивација за подвиг. Ипак, у првом плану је тумачење косовске катастрофе као Божје воље. Лазарева жртва се показује као достојна „венца мучеништва”. Тако се веома рано раздваја световна књижевна традиција, коју пре свега занима витешко-феудални подвиг и судбина оклеветаног и благородног појединца, од црквено-калуђерске, државне политичке традиције, која за свој предмет узима судбину државе „оличену у њеноме владару” (Шмаус 1964: 46). Територија Деспотовине, старањем Лазаревих наследника, постаје плодно тло за развој црквеног тумачења кнежеве жртве, које је неодвојиво од државно-политичког зрачења косовске легенде, без којега она не би могла да се развије у једну уистину модерну националну идеју, живу и животворну у вековима турског ропства.

Смрћу деспота Стефана Лазаревића замире и легенда о кнезу Лазару на просторима Деспотовине. Обнављала се два пута. Први пут у Русији старањем цара Ивана IV Грозног. Други пут у Срему, у сремској Раваници (Врдник), од 1697. године, са преносом кнежевих моштију пред Турцима.

\section{Легенда о Милошу Обилићу}

Обликована најпре као локална косовска традиција, легенда о оклеветаном јунаку који убија султана на пољу Косову, слична западноевропским витешким причама о односима господара и верног вазала, односно завидљивог сродника, кретала се даље од Српске деспотовине, према западу, ка Јадранском приморју. Тамо је и забележена. Отуда склоност

${ }^{4}$ У једном рукопису Константиновог житија из XVI века, поред имена 'благородног зело’ (веома) са стране је написано: Милош (в. Радојичић 1967: 217). 
појединих истраживача да порекло косовске легенде траже у западним крајевима. Чини се, међутим, да су од почетка постојала два, географски, тематско-мотивски и у идејном смислу међусобно раздвојена језгра косовске епске легенде, која се повезују тешњим везама тек са развојем мотива издајства Вука Бранковића.

И заиста, на западу, у Приморју, ствара се један нови књижевни и историографски круг у коме се развија низ епизода, непознатих у Моравској Србији наследника кнеза Лазара, које се укључују у живи ток косовске епске легенде. Анонимни преводилац познате грчке хронике Јована Дуке на италијански језик развија низ нових епизода косовске легенде. Он говори о тајним писмима која су измењивали турски цар Мурат и Милош Кобилић, „капетан Лазарев, човек и духом и телом толико пун крепости и снажан"; српски витез је писма показивао своме господару; ту је и мотив кнежеве вечере као и Лазареве здравице; затим се описује Милошев одлазак у турски табор „са блиставим копљем окренутим наопако”, што је мотив који се јавља и у турским изворима о Косовском боју (Ашикпаша Заде). Дукин преводилац први именује издајника, али ван главног тока косовске легенде. Он прича о томе да се током битке „пронео глас по читавом бојишту да се Драгослав Пробишић ("Dragossauo Probiscio”), капетан деспотов, „побунио и окренуо против хришћана”. Срби су, даље, поражени, а њихов кнез, „напуштен од својих капетана”, жив је заробљен, доведен под султанов шатор и тамо погубљен. Све ове податке Дукин преводилац је нашао „највероватније у савременим песмама, у првом реду усменим, које су се о косовској трагедији већ могле певати и које су се у то време и на нашем Приморју увелико волеле" (Пантић 1975: 340). У Коментарима о своме времену дубровачког историчара Лудвига Туберона Цријевића (писано између 1500. и 1527. године; објављено 1603. године) већ имамо развијен облик легенде: вечеру уочи боја, Лазареву здравицу и Милошев говор, клевету Милошевог такмаца и Милошев пребег у турски табор да би испунио своју заклетву. Милоша Кобилића зове Милоном, а можда и консултујући турске изворе о Косовском боју, говори о Милошевој руци, у сребро окованој, на Муратовом гробу у Бруси, седишту султановог култа.

Путопис кроз Босну, Србију, Бугарску и Румелију 1530 Бенедикта Курипечића, настао 1531. године, сведочи да се почетком XVI века „на целом хрватском и српском терену певају јуначке епске песме" (Латковић 1954: 333). Говорећи о гробу турског цара у Вучитрну, Курипечић у средиште пажње ставља Милоша Кобиловића, витеза чувена са својега јунаштва и поштења, о којему се и у Хрватској певају песме; описује га као „неког старог српског витеза”, неправедно оклеветаног код господара да шурује са непријатељем. Тиме је, уједно, дата и мотивација за подвиг. Говори се и о вечери у кнежевом табору, на којој је кнез многе младе пле- 
миће и дворјане посадио ,за свој сто и указао им почасти, а њега, старог витеза, пустио да стоји поред стола”. Ту је и Милошево зарицање да ће учинити подвиг. Сам подвиг је детаљно описан. У Путопису се уопште не говори о издајству на Косову. Очигледно је Курипечићев спис настао под утицајем народне традиције о Косовском боју. Истовремено, и овде имамо трагове легенде о Другом косовском боју будући да је путописац Мурата I заменио са Муратом II. Према неким тумачењима, у витешкој причи о Милошу Кобиловићу код Курипечића „имамо пред собом одјек стихом уобличене традиције, тј. најстарије песме о Милошу Обилићу” (Шмаус 1964: 51).

Да је легенда о Милошу Обилићу била веома рано развијена на Косову сведоче и други страни путници кроз Србију у XVI и XVII веку. Пролазећи Косовом они, по правилу, бележе Милошево име и подвиг, са веома занимљивим елементима који су преузети, вероватно, из локалне традиције. ${ }^{5}$

Лик Милоша Обилића обликује се поступцима историјске конкретизације. Од дванаест заверених племића који су, према изворима из године боја, прокрчили себи пут до султановог чадора и извршили подвиг, издваја се најпре један непознати благородник, неправедно оклеветан да ће издати свог господара (Житије деспота Стефана Лазаревића Константина Филозофа), да би затим, најпре у страним изворима (византијски историчар Лаоник Халкокондил, турски Ашик-паша Заде), добио име, а касније и развијену епску биографију.

„Предисторија” Милошеве легенде, „обликована првобитно у западним крајевима", значајно је употпуњена причом о завади Лазаревих зетова. Ову причу први пут срећемо у спису Tрактат о Турциима пушкара (тополивца) Јерга из Нирнберга. Развијајући мотив неслоге међу хришћанима, Јерг први уноси овај мотив, који представља важну карику у повезивању епизода косовске легенде (Спремић 1991: 44). Дубровачки историчар Мавро Орбин у Краљевству Словена (1601) допуњује мотив о завади зетова елементом свађе Лазаревих кћери, Маре и Вукосаве, око првенства њихових мужева. Код Орбина су присутни сви елементи развијене косовске легенде: кнежева вечера, здравица, Милошева беседа, подвиг. Милош је „у

${ }^{5}$ У Дневнику путовања по Турској (1573-1578) Немца Стефана Герлаха помиње се предање о развалинама Милошева града код Пирота. „Кнеза Мила” и тврђаву Милешевац помиње Француз Филип Дифрен-Кане 1573. године. Жан Палерн Форезјен 1582. године говори о подвигу „Мила Комнена”, који је усред турског табора погубио Мурата Другог. Занимљиво је да он помиње и традицију по којој су Турци ухватили косовског подвижника „посредством једне вештице”. Чех барон Вратислав, на свом путовању кроз Србију у Цариград у аустријском посланству 1591. године, помиње аудијенцију код султана, као и обичај да се добро претресу они који излазе код цара, уведен после погибије султана Мурата на Косову. 
освит зоре, а да нико није приметио", узјахао коња и с копљем окренутим наопако, „што је код Словена знак бегунца”, отишао у турски табор. Бацивши се на земљу, „како је обичај код Турака”, клањао се цару пригнуте главе да му пољуби руку, крадимице извукао бодеж, скривен у недрима, и забио га цару у трбух. Затим је „из петних жила” покушао да побегне из шатора, али га је ранила царева стража и ту је погинуо. Приказано је и заробљавање кнеза Лазара који, бежећи, упада „заједно с коњем у једну невидљиву рупу покривену земљом и грањем коју су сељаци ископали да би ухватили неку звер". Лазар је жив ухваћен, глава му је одрубљена, и покопан је у Раваници. Мавро Орбин први упире прстом на Вука Бранковића као на издајника. ${ }^{6}$ Вука Бранковића ће после Орбина, а служећи се њиме, за издајство на Косову оптужити сви познији историјски и традицијски извори. По Аналима Ј. Лукаревића, када је, после смрти Балше III, деспот Стефан Лазаревић послао у Зету Вуковог сина Ђурђа, нису хтели да га приме ,због љаге издаје његовог оца”.

У најстаријим историјским изворима јунак који је убио султана Мурата био је безимен („неко веома благородан”). Око Милоша Обилића се од XV века плете витешка прича о оклеветаном јунаку који убија султана на Косову. Старије верзије Милошевог презимена су Кобиловић, Кобилић и Драгиловић, да би се у XIX веку усталило презиме Обилић. Историја не зна ни за Милошеве епске побратиме, Косанчић Ивана и Милана Топлицу. Имена су добили по рекама Косаници и Топлици чије се воде сливају у Јужну Мораву.

Милош у епској поезији носи обележја змајевитог јунака: младеж на десној мишици, на младежу „бич вучије длаке”, на бедрима му је „сабља уписана” и сл. Поседује коња натприродних особина - „виловити Ждралин". Оружје му је земаљског (копље, сабља, топуз), али и божанског порекла (,сабља виловита”).

Милош Обилић није потврђен у историји као зет кнеза Лазара. Његов подвиг је јединствен и неупоредив са другим јунацима. У предањима о пореклу Милошевог презимена посебно се истичу чудесне особине детета које српски цар Душан Немањић проналази у планини:

„Срби приповиједају да је Силни Стефан ловећи по Церу угледао на једном мјесту гдје се гране од дрвећа и доље савијају и горе узвијају. Кад дођу на оно мјесто, а то дијете код неколико оваца ударило своју сјекиру у кладу па легло на леђа те спава: кад дихне из себе онда се гране узвијају у висину, а кад повуче пару у се, онда се савијају к земљи. Кад то види цар, зачуди се, па пружи руку с

\footnotetext{
${ }^{6}$ „Међутим, зет кнеза Лазара Вук Бранковић спасао се готово са свим својим људима, пошто је (како неки кажу) имао тајне преговоре с Муратом да изда (како је и учинио) свога таста да би се докопао његове државе. Тако је после његове смрти и остао господарем једног дела Рашке, док је други добила његова жена Милица и Лазарева два нејака сина, Стефан и Вук."
} 
коња да му узме сјекиру, али хоћеш! не може да је извади из кладе. Брже боље сјашу слуге и војводе с коња, огледају сви редом објема рукама да изваде сјекиру из кладе, али је ниједан не може ни помаћи. Онда пробуде дијете и запита га цар: 'Како ти је име?' А оно одговори: 'Милош.' 'Имаш ли оца и мајку?' 'Мајку имам, а отац ми је умро.' 'А гдје ти је мајка?' 'Ето је тамо доље у селу код куће.' 'Ајде да нас водиш кући.' 'Не могу од оваца.' - И тако га којекако намоле да потјера овце и да пође пред њима кући. Сад су они ради знати и видјети шта ће он радити са сјекиром, како ће је извадити из кладе; или ће је онако оставити. Кад Милош крене овце, а он узме сјекиру једном руком и заметне на рамо.” (Како је постало име Обилић, одломак, Вук, Етнографски списи, 13-15)

Сачувана су и друга предања о Милошу Обилићу. Народ верује да је Милош Обилић био родом из Поцерине, а да су му у селу Дворишту били двори. О манастиру Каона предање каже да је подигнут као задужбина Милошеве сестре Иконије.

Владика Петар II Петровић Његош је 1847. године установио златну медаљу Обилића као највише црногорско војничко одликовање. Указом краља Петра I Карађорђевића 1913. године установљена је Медаља за храброст са попрсјем Милоша Обилића.

И поред тога што је у традицији представљен као побратим Марка Краљевића, око Милоша Обилића није створен посебан круг народних песама, те своје „првобитно и право место он има у косовском циклусу” (Шмаус 1964: 43).

Милош је заступник витешког слоја косовске легенде, у који спадају епизоде о кнежевој вечери, напијање чаше, опадање јунака, заклињање на подвиг, ухођење турске војске, подвиг, смрт и завештање. Али је Милош Обилић и митски јунак (в. Поповић 1976). У низу сижејних модела он је „део митске свести, део старих веровања” (Михаљчић 1989: 43). Милошев косовски завет скрива у себи врло старе паганске честице разореног мита: „У Милошевом завету препознајемо веома старе, чак и паганске детаље мегдана (Милош уместо жртвеног јагњета убија султана, стаје пораженом противнику ногом под грло), а помињу се и Видов данак и Бог велики" (Матицки 1999: 106). Митски је обележен и начин хватања јунака у бугарштичкој традицији и у локалним предањима са Косова и Метохије (Љубинковић 1992: 63-64). У свести народа, Милош није ништа друго „до сушти мит” (Нодило 2003: 329). Смисао мита о „пра-Милошу” може се тражити и ван словенског круга, у развијеним митологијама старих Нордијаца и Иранаца (Лома 2002: 215). 


\section{Легенда о Вуку Бранковићу}

Развојем мотива издаје, нарочито од XVII века, комплетира се слика косовске епске легенде. И овде је, као и у развоју мотива о оклеветаном јунаку који врши подвиг, уочљив процес епске историзације. Наиме, уместо неодређеног мноштва „завидљиваца” код Константина Филозофа постепено се издваја само један Милошев противник, завидљиви зет који најпре оклевета супарника господару, а затим и изда свога сизерена на бојном пољу. Тако се и из групе завереника у одговору Фирентинске општине, са развојем косовске легенде, акценат усредсређује на једног јунака који врши подвиг. У најстаријим српским летописима (Пећки летопис ${ }^{7}$ ) издаја је дата веома магловито. У познијим летописима (Студенички летопис ${ }^{8}$ ) већ се сасвим одређено говори о неверству и бекству српских чета. У Турској хронищи Константина Михаиловића из Островице мотив издаје везује се за групу људи. Дукин преводилац прича да се током битке „пронео глас по читавом бојишту да се Драгослав Пробишић ('Dragossauo Probiscio'), капетан деспотов, побунио и окренуо против хришћана". Вука Бранковића као издајника први помиње Мавро Орбин у Краљевству Словена (1601), а затим и Бранковићев летопис, непознати Пераштанин у драми Бој кнеза Лазара, рукописна Прича о боју косовском, Подгорички летопис, Троношки родослов, као и народне песме (Ређеп 1976: 86).

Издаја Вука Бранковића била је карика која недостаје да би косовска легенда била потпуна. Без ове издаје не би било тешњих веза између Лазареве и Милошеве легенде. Не би било ни ваљаног објашњења српског пораза, како је забележен у колективном народном памћењу. Милошев подвиг би остао у великој мери проблематичан, будући да би представљао чин увређеног појединца, условљен личном таштином. Појавом Вука Бранковића у улози издајника појачава се трагична димензија у лику и поступцима кнеза Лазара. Интензивира се драмски набој. Сви актери догађаја повезују се родбинским везама. Асоцира се на библијску издају, посебно у развоју мотива кнежеве вечере. Наглашава се судбинска предодређеност косовске катастрофе, најизразитије у епским песмама Вукове збирке. Преузимањем мотива издаје Вук Бранковић постаје „тип издајника” у колективном памћењу. Легенда о Вуковој издаји толико је ушла у све поре духовног, историјског и културног живота српског народа да су припадници критичке историографије, борећи се против ове заблуде, у јавности свога доба били жигосани као „разоритељи заветне мисли”,

${ }^{7}$ „И на крају боја тога, не знам шта истинито рећи о овом (Лазару), да ли је издан од неког из његове дружине или се напротив суд божји испунио на њему."

${ }^{8}$ У Студеничком летопису се каже: „,.. а неки страха ли ради или неверства свога ради побегоше". 
људи који „трују и убијају народни дух и исмевају осећај народни”, клеветници и непатриоте.

Вук Бранковић је био моћан српски великаш. Потицао је из старе и угледне породице. Био је ожењен ћерком кнеза Лазара. У једном документу забележено је да су кнез Лазар и Вук ,у јединству и љубави побеђивали непријатеље своје”. Вук Бранковић није био издајник. Завршио је свој живот у турском ропству. Вероватно је један од разлога што је остао упамћен у традицији као нечастан и вероломан човек то што је преживео Косовску битку.

Данас знамо да није било разлога да Вук изда на Косову. Бој се одиграо на његовој територији. Чак и да је издао кнеза Лазара, Вук није имао куда да побегне са бојног поља. Вуков грех је можда у томе што је преживео Косово. У епици која пева о колективној смрти целе једне генерације ратника на бојном пољу то је био чин раван издаји.

Не треба занемарити ни настојања Српске цркве да се заташка успомена на Вука Бранковића у српском колективном памћењу. Око његовог имена у српским историјским изворима онога доба влада мук. Летописци само узгред помињу његову смрт. Ни Ђурађ Бранковић не помиње свога оца, чак и онда када би то било сасвим умесно.

\section{Турски извори о Косовском боју}

Паралелно, и готово истовремено са српским, јављају се и турске вести о Косовском боју. Оне, по правилу, акценат стављају на време и околности погибије султана Мурата, на неверника који је убио падишаха (цара) и начин на који је султан постао шехит (мученик за веру). У њима, међутим, налазимо, сасвим неочекивано, важне мотиве српске епске усмене легенде о Косовском боју, као што су мотиви кнежеве вечере, здравице, ухођења Турака, Милошевог завета да ће извршити подвиг, извршења подвига, Муратовог склапања фиктивног уговора са Вишњом Истином, султанове последње воље. Код појединих турских хроничара (Нешри, Битлиси) чак налазимо детаље којих нема у оновременим хришћанским изворима, а касније их срећемо као незаобилазне елементе у потпуно оформљеној причи о боју на Косову у забележеним епским песмама дугога и краткога стиха.

Стихови дворског песника Ахмедије (1334-1413), савременика боја и писца најстаријег турског епоса Искендернаме (Александрида), чија је прва редакција довршена 1390. године, дакле непосредно после Боја, представљају до данас најстарију познату турску вест о боју на Косову и о погибији Муратовој. По овој верзији, Мурат је погинуо у „последњој фази боја", на чему инсистирају и сви познији турски извори. Османске историје (Теварих-и Ал-и Осман) једренског историчара Уруџа, писане 
око половине XV века, сматрају се најстаријим прозним делом о турској историји. Говорећи о Косовском боју, Уруџ први и једини од турских историчара тврди да је Мурат убијен за време боја, а да су тек после избора Бајазита за цара и погубљења Јакубова, турски бегови разбили хришћанску војску и заробили кнеза Лазара.

Један од најзанимљивијих турских извора за нас јесте опис Косовског боја у историји званичног историчара султана Бајазита II, Мехмеда Нешрија Огледало света, као и хроника Нешријевог савременика Идриза Битлисија. Нешријев текст показује недвосмислене утицаје српске косовске традиције, како на тематско-мотивском плану, тако и у лексичком (речи типа господар, витез, за Бога) и стилско-композиционом погледу (Нешри свако поглавље започиње фразама које су карактеристичне за поетику усмених предања, типа: каже се, приповеда се, приповедају). Сем тога, у својој варијанти Муратове погибије, Нешри уноси и епизоду о мистичном уговору између султана Мурата и Вишње Истине, чиме се сугерише да је сам Муратов убица „само оруђе у рукама Вишње Истине”. Нешри бележи неке важне детаље косовске епске легенде, који у списима хришћанских извора о Косовском боју из XV и XVI века недостају: мотив избора царства небескога или ияарства земаљькога и, пре свега, мотив ухођења турске војске, које „Нешрија бележи у таквом облику да је њихово српско порекло ван сваке сумње" (Љубинковић 1961: 163). Нешри је српску косовску традицију могао упознати у Бруси, где је после Косовског боја пренето тело султана Мурата и свакако веома рано био развијен његов култ, али где се, по писању дубровачких историчара, налазила и Милошева у сребро окована рука, што би могло сугерисати и постојање врло рано развијеног светитељског култа Милоша Обилића. Сем тога, сама концепција лика султана Мурата у Нешријином спису остварена је као пандан светитеља и мученика за веру, у врло рано оформљеном култу кнезу Лазару. Нешри у својој историји бележи и податак о припремању српске војске за ноћни препад на Турке, чији је иницијатор био сам кнез Лазар, а од кога се одустало по наговору неког кнежевог војсковође Југе - никако безначајног будући да је заповедао војском од девет хиљада људи - и то у последњем тренутку.

Турски списи посебну пажњу поклањају убици падишаха, према коме се, истина, погрдно односе, али при том не скривају ни његов углед у противничкој војсци. Тако, по Ахмедију, убица је „неки каурин (гебр)” који, је, сакривен међу труповима, улучивши згодну прилику, ударио хана ханџаром. Уруџ говори о томе да је убица био ,,један од моћних неверничких бегова”. Анонимни дервиш из Једрена говори о „неком проклетом невернику, неваљалцу”, који је био „чувен међу њима по одважности, злоби и лукавству". Шукрулах такође наглашава да је међу лешевима био сакривен „један неверник, будући рањен и укаљавши се крвљу”. Ашик-паша Заде 
први именује „проклетника” као јунака по имену Билиш Кјуб-ила, правећи од тога игру речима, „онај који уме задати ударац”. И Нешри бележи име „проклетог неверника” - то је Милош Кобила (в. Зиројевић 1989: 254).

За Идриса Битлисија Милош је „онај стари дволичњак”, „слика и прилика проклетог ђавола". Он падишаха убија отровним ханџаром, заривши му нож у трбух, чиме сам стиче славу међу „поквареним невјерницима”, али и самог султана доводи до ,херојске части (шахадат) међу владарима свијета". Битлиси, дакле, говори о томе да је Милош Никола (?!) један од најугледнијих ,краљева” неверничке војске; у циљу извршења подвига он постаје муслиман; за своју акцију користи отровни ханџар; и, што је најважније, он је један од оних „седам опаких невјерничких владара” које је принц Бајазит јуначки поразио у другом делу битке, преокренувши тако ситуацију од првобитних хришћанских успеха, до њиховог потпуног пораза. Питање је да ли треба „овде тражити и далеки ехо јуначког подвига дванаесторице племића који су се, судећи по одговору Фирентинске републике краљу Твртку, пробили до Амуратовог шатора" (Зиројевић 1989: 256-257).

Када су турски извори о Косовском боју у питању, не треба занемарити ни путописца Евлију Челебију који је, у XVII веку, управо на терену где се збио Косовски бој, забележио низ предања о Милошу Обилићу. Још важније за изучавање косовске усмене епске традиције јесте то да се у путопису Евлије Челебије први пут јавља мотив, касније веома популаран у српској усменој косовској традицији, о некаквој тајанственој баби која казује Турцима како да погубе косовског подвижника. Занимљиво је да епизоду о бабином носу срећемо и у дубровачкој барокној поезији. Дубровчанин Јакета Палмотић (1625-1680) уноси у девето певање свога епоса Дубровник поновљен ово предање, које је чуо док је, путујући као поклисар с харачем за Порту Косовом, прелазио преко моста, који су становници називали Бабиним Носом. Иако је у питању предање потекло са терена Косова, о чему нам несумњиво сведочи забележена локална косовска усмена традиција 9 , Палмотићев епос нам ипак довољно говори о популарности косовске легенде, чији су се препознатљиви сегменти веома лако ширили и уклапали у нове обрасце.

Овај мотив срећемо и у народним песмама и предањима о Косовском боју. Демонско биће које открива Турцима начин на који ће савладати Милоша Обилића именује се као „проклета баба”, и то у српскохрватској, муслиманској, албанској, македонској и бугарској усменој традицији. У неким песмама она се именује као „баба из буџака” (Босанска вила за 1886.

\footnotetext{
${ }^{9}$ „У другим народним песмама о косовскоме боју, као и у новијим записима народнога предања са Косова доследно се говори да Турцима баба помаже. Баба и јесте одговарајући назив за оно што саветује Турке. Реч је, према истраживањима Веселина Чајкановића, о женском хтоничном божанству, чији је атрибут жаба" (Љубинковић 1992: 64).
} 
годину); „из стијене бабетина” (Петрановић III, бр. 26), или „Глас како женски" (Стојан Новаковић, Народна предана о боју косовском, Старине $\mathrm{X}, 197)$; у једној од најстаријих бугарштица о Косовском боју наводи се „глас из облака”:

Глас изиде из облака и Турцима говораше:

Али, Турци, не видите, испале вам црне очи

ђе је Милош оклопљен и под њиме коњиц добар

(Богишић, бр. 1)

\section{Косовска легенда на Косову и Метохији}

Локална косовска традиција без сумње је у потпуности обузета Милошевим подвигом. Поред српских усмених предања и епских песама које нам о томе говоре, у духу са основним тоном турских извора, које нагласак стављају на султанову погибију, односно Милошев подвиг, креће се и забележена муслиманска и албанска традиција о Косовском боју поникла на исходишту легенде. Симболично, око Муратовог турбета и, можда, Милошеве цркве, на митском пољу одсудног сукоба, сучељавају се и преплићу, свијају се као бршљан једна око друге, две косовске традиције, српска и муслиманско-арбанашка, по националним, верским и политичким интенцијама супротне, али истог тона, духа, композиционог склопа и тематско-мотивске основе, израсле на истом живом, а незараслом тлу крви, херојства и патње (Љубинковић 1992: 56). У две приче о Косовском боју из рукописа Дене Дебељковића сусрећу се српска и албанска косовска традиција (Чајкановић 1927, бр. 141).

Карактеристично је да и локална албанска и муслиманска традиција, забележене у готово идентичном облику, имају један мотив који је непознат нашим народним песмама - Милош носи своју главу у руци после погубљења. По Ненаду Љубинковићу, то је настало као утицај култа Светог Јована Владимира, пореклом из Албаније, из Елбасана, који су Албанци, када су се доселили на Косово, повезали са традицијама које су ту затекли, пре свега са новоствореним култом Милоша Обилића, који је веома рано почео да се негује на Косову.

Идејно, стилско и тематско-мотивско јединство косовске легенде, најрепрезентативније илустровано у песмама из Вукове збирке, представља једну, у српском народу и данас живу и актуелну мисао. Непрестано подложна самоиспитивањима и променама, а неизмењивог духовног корена и састава, у историјском развоју српског национа она као да још увек бди над његовом епском духовношћу. 


\section{ЛИТЕРАТУРА}

Банашевић 1936: Никола Банашевић, О постанку и развоју косовског и Марковог циклуса, Прештампано из Српског књижевног гласника, н. с., књ. XLVII, бр. 7-8, 1936.

Бандић 1990: Душан Бандић, Царство земаљско и царство небеско. Огледи о народној религији, Библиотека XX век, Београд.

Башагић 1924: Сафет-бег Башагић, Најстарија турска вијест о Косовском боју, Гласник Земаљског музеја у Босни и Хериеговини, XXXVI, 95-99.

Божић 1975: Иван Божић, Неверство Вука Бранковића, у зборнику О кнезу Лазару, Београд, 1975.

Бошковић-Стули 1991: Maja Bošković-Stulli, Baladni oblici bugarštica i epske pjesme (1988). Pjesme, priče, fantastika, Zavod za istraživanje folklora, Posebna izdanja 15, Zagreb: Nakladni zavod Matice hrvatske.

Вукановић 2001: Татомир Вукановић, Енциклопедија народног живота, обичаја и веровањ а Срба на Косову и Метохији, VI век - почетак ХХ века, Београд.

Гиљфердинг 1972: Александар Гиљфердинг, Путовағе по Хериеговини, Босни и Старој Србији, прев. Б. Чулић, Сарајево.

Гура 2005: Александар Гура, Симболика животињ а у словенској народној традищији, Београд: БРИМО, ЛОГОС, „ГЛобосино”-АЛЕКСАНДРИЈА.

Деретић 2000: Јован Деретић, Српска народна епика, Београд: Филип Вишњић.

Детелић 1992: Мирјана Детелић, Митски простор и епика, Београд: САНУ, Посебна издања, књ. DCXVI, Одељење језика и књижевности, Књ. 46.

Динић 1992: Михаило Динић, Историјско и легендарно Косово, у зборнику: Бој на Косову - старија и новија сазнања, ред. Раде Михаљчић, Књижевне новине, Београд, 441-442.

Дрндарски 1997: Мирјана Дрндарски, Тајна вечера у епским народним песмама - од калка до транспозиције, Научни састанак слависта у Вукове дане, 26/1, 139-143.

Елезовић 1940: Глиша Елезовић, Бој на Косову у историји Муле Мехмеда Нешрија, Браство, XXXI, Београд, 1-77.

Зиројевић 1989: Олга Зиројевић, Милош Обилић у турским изворима, у зборнику: Свети кнез Лазар. Споменица о шестој стогодишњици Косовског боја 1389-1989, Београд.

Зуковић 1986: Љубомир Зуковић, Гргуревачка шљепица - пјевач Вука Караџић, Godišnjak Instituta za književnost u Sarajevu, XV, 171-191. 
Ивић 1993: Милка Ивић, Запис о Косовском боју, у: Списи о Косову, прир. Милица Грковић, Едиција Стара српска књижевност у 24 књиге, књ. 13, Просвета-СКЗ, Београд, 86-90.

ИСН 1981: Историја српског народа I, Београд: СКЗ.

Јиречек/Радонић 1988/I-II: Константин Јиречек, Историја Срба I-II, превео и допунио Јован Радонић, Београд.

Ковачевић 1888: Љубомир Ковачевић, Вук Бранковић, Београд.

Константин Филозоф 1989: Константин Филозоф, Повест о словима (Сказаније о писменех). Житије деспота Стефана Лазаревића, Едиција „Стара српска књижевност у 24 књиге”, књ. 11, прир. Гордана Јовановић, Просвета-СКЗ, Београд.

Константиновић 1989: Зоран Константиновић, Пушкар Јерг из Нирнберга о Босни и Србији, у: Косово у памћењу и стваралаштву, 41-49.

Косово 1389 - 1989. Земља живих, прир. В. Арсенијевић, Београд, Ћелија Пиперска, 1989.

Косово у памћењу и стваралаштву, прир. Ненад Љубинковић, Београд 1989. (темат часописа Расковник, бр. 55-56).

Косово. Народне песме о боју на Косову 1389. године, прир. Тихомир Остојић, Нови Сад, 1901.

Косово. Српске народне пјесме о боју на Косову. Покушај да се саставе у цјелину као спјев, прир. Стојан Новаковић, Биоград, 1871.

Косовска битка 1389. године и њене последице, Међународни симпозијум, Химелстир 1989, ур. Н. Тасић, В. Ђуретић, Београд, 1991.

Косовски бој у српској књижевности, ур Војислав Ђурић, Београд, 1990.

Костић 1939: Драгутин Костић, Два косовска цикла, Прилози проучавању народне поезије, год. VI, св. 1, Београд.

Костић 1989: Др. Костић, Најстарија забелешка о боју на Косову писана од очевидаца за време саме битке, Време, 16. јануар 1929, 4.

Крстић 1939: Бранислав Крстић, Пророчанства о косовском боју, Прилози проучавању народне поезије, 1939, VI, 1, 47-53.

Лазарица или Бој на Косову. Народна епопеја у 24 песме, Из народних песама и њихових одломака саставио Срета Ј. Стојковић, друго, допуњено издање, Београд, 1906.

Латковић 1954: Видо Латковић, Бенедикт Курипечић. Путопис кроз Србију, Бугарску и Румелију 1530, превео Ђ. Пејановић. Сарајево 1950, Прилози за књижевност, језик, историју и фолклор, књ. ХХ, св. 3-4, 333-335.

Лома 2002: Александар Лома, Пракосово. Словенски и индоевропски корени српске епике, Српска академија наука и уметности, Балканолошки институт, Посебна издања 78, Београд. 
Љубинковић 1961: Ненад Љубинковић, Opis kosovskog boja kod turskog istoričara Mule Nešrija i naše narodne kosovske pesme, Glasnik Muzeja Kosova i Metohije, VI, Priština, 1961, 161-170.

Љубинковић 1989: Н. Љубинковић, Косовска битка у своме времену и виђењу потомака или логика развоја епских легенди о Косовскоме боју, у: Косово у памћењу и стваралаштву, прир. Ненад Љубинковић, Расковник, Београд, књ. 55-56, 127-164.

Љубинковић 1992: Ненад Љубинковић, Најстарији записи прозних народних предања о Косовскоме боју на простору Косова, у: Зборник у част Војислава Ђурића, уредник Иво Тартаља, Београд: Просвета (посебан отисак).

Љубинковић 1996: Н. Љубинковић, Транспозиција историјских чињеница у епско и митско ткиво епске легенде - легенда о Косовскоме боју, легенда о Марку Краљевићу, у зборнику Од мита до фолка, Библиотека „Лицеум”, књ. 2, Крагујевац, 1996.

Маретић 1889: Tomo Maretić, Kosovski junaci i događaji u narodnoj epici, Rad JAZU, 1889, XCVII, 69-181.

Матицки 1999: М. Матицки, Историја као предање, Културно- просветна заједница Србије, Београд.

Матић 1983: Војин Матић, Митске личности у косовском боју, у: Психоанализа митске прошлости III, Београд, 1983, 109-143.

Милошевић-Ђорђевић 1983: Нада Милошевић-Ђорђевић, Појам историјске баладе и епска народна песма „Косовка Дјевојка”, Кьижевност и језик, XXX, 4, 231-239.

Милошевић-Ђорђевић 1990: Н. Милошевић-Ђорђевић, Косовска епика, Завод за уџбенике и наставна средства, Београд.

Милошевић-Ђорђевић 2000: Н. Милошевић-Ђорђевић, Косовска легенда и српски средњовековни списи, Зборник Матице српске за књижевност и језик, XLVIII, 1, 7-34.

Милошевић-Ђорђевић 2011: Н. Милошевић-Ђорђевић, Радост препознавања, Нови Сад: Матица српска.

Михаиловић 1959: Константин Михаиловић из Островице, Јаничарове успомене или Турска хроника, превод и предговор Ђорђе Живановић, Споменик САНУ, CVII, Београд, 1959 (Београд, 1966, 1986).

Михаљчић 1989: Раде Михаљчић, Јунаци косовске легенде, друго издање. БИГЗ, Београд.

Михаљчић 1989а: Р. Михаљчић, Лазар Хребељановић-историја, култ, предање, друго издање.

Најстарији српски записи о Косову, у: Списи о Косову, прир. Милица Грковић, Едиција Стара српска књижевност у 24 књиге, књ. 13, Просвета-СКЗ, Београд, 1993, 177-178. 
Недић 1973: Владан Недић, Марко Утвић, певач Вука Караџића, Прештампано из Зборника Матице српске за књижевност и језик, књ. XXI/3, 1973.

Недић 1990: Вл. Недић, Вукови певачи, предговор и приређивање Р. Пешић, поговор Сл. Гароња, Београд: Рад.

Нодило 2003: Natko Nodilo, Stara vjera Srba i Hrvata, Beograd: MVTC.

О кнезу Лазару, Научни скуп у Крушевцу, 1971, Београд, 1975.

Олесницки 1935: Алексеј Олесницки, Турски извори о Косовском боју, Гласник Скопског научног друштва, књ. XIV, Скопље, 59-98.

Орбин 1968: Мавро Орбин, Краљевство Словена, превео З. Шундрица, коментари С. Ћирковић, Београд: СКЗ; Орбин 2006²: М. Орбин, Краљевство Словена, Зрењанин: SEZAМВООК.

Павић 1877: Armin Pavić, Narodne pjesme o boju na Kosovu, godine 1389, Zagreb, 1877.

Павловић 1965: Леонтије Павловић, Култови лииа код Срба и Македонаиа (Историјско-етнографска расправа), Народни музеј Смедерево, Посебно издање књ. 1, Смедерево, 1965.

Пантић 1975: Мирослав Пантић, Кнез Лазар и Косовска битка у старој књижевности Дубровника и Боке Которске, у зборнику: $O$ кнезу Лазару, Београд, 383-406.

Перић 2008: Драгољуб Перић, Териоморфни јунаци словенске епике. Волх Всеславјевич и Змај Огњени Вук (компаративно-типолошка анализа), Библиотека Од злата јабука, књ. 3, ур. Милош Јевтић, Београд: Београдска књига.

Петровић 2001: Косовска битка у усменој поезији, прир. Соња Петровић, Српске народне умотворине, књ. 3, уредник Миле С. Баврлић, Београд: Гутенбергова галаксија.

Пешић 1996: Радмила Пешић, Кратке народне песме о кнезу Лазару, Даница, Српски народни илустровани календар, 189-193.

Питулић 2007: Валентина Питулић, Семантика божура: усмено Косово, Београд: КИЗ Алтера - Филозофски факултет: Косовска Митровица.

Поповић 1976: Миодраг Поповић, Видовдан и часни крст. Оглед из књижевне археологије, Београд: Слово љубве.

Раденковић 1996: Љубинко Раденковић, Симболика света у народној магији Јужних Словена, Београд: Балканолошки институт САНУ - Ниш: Просвета.

Радојичић 1937: Ђорђе Сп. Радојичић, Савремене вести о косовској битци код руског путописца ђакона Игњатија, Старинар, 1937, III, 47-54.

Радојичић 1967: Ђорђе Сп. Радојичић, Почетак косовске легенде, у: Књижевна збивања и стварања код Срба у средњем веку и у турско доба, Нови Сад. 
Рачки 1992: Фрањо Рачки, Бој на Косову. Узроци и посљедице, у: Бој на Косову - старија и новија сазнања, ред. Р. Михаљчић, Књижевне новине, Београд.

Ређеп 1976: Јелка Ређеп, Прича о боју косовском, Зрењанин.

Ређеп 1991: Јелка Ређеп, Косовска легенда и Прича о боју косовском, у зборнику: Косовска битка 1389. године и юене последице, САНУ, Балканолошки институт, Посебна издања, књ. 44, Београд.

Peђеп 1998: Ј. Ређеп, Мотив издаје на Косову у бугарштицама, у: Убиство владара. Студије и огледи, Прометеј, Нови Сад.

Руварац 1887: Иларион Руварац, О кнезу Лазару, Нови Сад 1887.

Самарџија 2008: Снежана Самарџија, Биографије епских јунака, Библиотека „Књижевност и језик”, књ. 27, Београд: Друштво за српски језик и књижевност Србије.

Самарџић 1978: Радован Самарџић, Усмена народна хроника, Нови Сад: Матица српска, Нови Сад.

CM 2001: Словенска митологија. Енциклопедијски речник, редактори Светлана M. Толстој, Љубинко Раденковић, Београд: ZEPTER BOOK WORLD.

CMP 1998: Шпиро Кулишић, Петар Ж. Петровић, Никола Пантелић, Српски митолошки речник, друго допуњено издање, Етнографски институт САНУ, припремио и уредио Никола Пантелић, Београд: Интерпринт.

Спремић 1991: Момчило Спремић, Косовска битка - проблем издаје, у зборнику: Косовска битка 1389. године и юене последице, САНУ, Балканолошки институт, Посебна издања, књ. 44, Београд.

Станојевић 1936: Станоје Станојевић, Кад је убијен цар Мурат?, Гласник Скопског научног друштва, Скопље 1936, књ. XIV-XVI, 145-152.

Сувајџић 1998: Бошко Сувајџић, Рецепција косовског предања у бугарској фолклорној традицији, Српски језик, 1998, 3, 491-515.

Сувајџић 2005: Б. Сувајџић, Јунаци и маске. Тумачења српске усмене епике, Библиотека „Књижевност и језик”, Београд: Друштво за српски језик и књижевност Србије.

Томац 1968: Петар Томац, Косовска битка, Београд.

Томић 1908: Јован Томић, Бој на Косову, Нови Сад.

Трифуновић 1968: Ђорђе Трифуновић, Српски средњовековни списи о кнезу Лазару и Косовском боју, Крушевац: „Багдала”.

Трифуновић 1975: Ђ. Трифуновић, Косовско страдање и небеско царство, у зборнику: $О$ кнезу Лазару, Београд.

Трифуновић 1989: Ђ. Трифуновић, О почецима штовања кнеза Лазара, Научни састанак слависта у Вукове дане, 19/1, 123-131.

Ћирковић 2005: Сима Ћирковић, Срби у средњем веку, Београд: Idea. 
Чајкановић 1994 II: Веселин Чајкановић, Студије из српске религије и фолклора 1925-1942. Сабрана дела из српске религије и митологије, књ. ІІ, прир. Војислав Ђурић, Београд: СКЗ, БИГЗ, Просвета, Партенон М.А.М.

Челеби 1967: Евлија Челеби, Путопис, одломии о уугославенским земљама, превео, увод и коментар написао X. Шабановић, Сарајево.

Шмаус 1936: Алојз Шмаус, О косовској традицији код Арнаута, Прилози проучавању народне поезије, III, 1, 73-90.

Шмаус 1964: Alois Schmaus, Милош Обилић у народном песништву и код Његоша, Рад X-ог конгреса Савеза фолклориста Југославије на Цетиюу 1963, Цетиње. 